Economics Development Analysis Journal 6(3)(2017)

\title{
Dampak Pengembangan Pariwisata Terhadap Perekonomian Masyarakat Sekitar Objek Wisata di Dieng Kabupaten Wonosobo
}

\author{
Sani Alim Irhamna ${ }^{凶}$
}

Jurusan Ekonomi Pembangunan, Fakultas Ekonomi, Universitas Negeri Semarang

\begin{tabular}{|c|c|}
\hline Info Artikel & Abstrak \\
\hline Sejarah Artikel: & \\
\hline $\begin{array}{l}\text { Diterima April } 2017 \\
\text { Disetujui Juni } 2017 \\
\text { Dipublikasikan Agustus } \\
2017\end{array}$ & $\begin{array}{l}\text { Penelitian ini mengidentifikasi dampak yang ditimbulkan dari adanya pengembangan objek wisata } \\
\text { terhadap kondisi perekonomian masyarakat sekitar. Penelitian ini dilakukan di Desa Dieng, } \\
\text { Kecamatan Kejajar, Kabupaten Wonosobo. Penelitian ini dilakukan karena meningkatknya } \\
\text { pengunjung objek wisata dan pendapatan sektor pariwisata yang berpengaruh terhadap } \\
\text { perekonomian masyarakat sekitar objek wisata. Jenis penelitian ini menggunakan metode penelitian }\end{array}$ \\
\hline $\begin{array}{l}\text { Keywords: } \\
\text { The Impact of Tourism } \\
\text { Development, The Economic } \\
\text { of Local Society. }\end{array}$ & $\begin{array}{l}\text { deskriptif yang dilengkapi data kualitatif dan kuantitatif baik data primer maupun sekunder. } \\
\text { Penelitian ini menggunakan alat Skala Likert untuk menentukan hasil penelitian. Tujuan dari } \\
\text { penelitian ini untuk mengetahui gambaran kondisi pariwisata, dan mengidentifikasi dampak yang } \\
\text { ditimbulkan dari adanya pengembangan pariwisata terhadap kondisi perekonomian masyarakat } \\
\text { sekitar. Hasil dari penelitian ini menunjukkan adanya peningkatan fasilitas, pelayanan objek wisata }\end{array}$ \\
\hline & $\begin{array}{l}\text { setelah adanya pengembangan, akan tetapi ada penurunan pada bidang kebersihan dan keamanan. } \\
\text { Persentase pendapatan masyarakat mengalami peningkatan yang dihitung menggunakan Skala } \\
\text { Likert dari 53,3\% menjadi } 68,5 \% \text {, tingkat kesempatan kerja rendah dengan persentase hanya sebesar } \\
29,5 \% \text {. }\end{array}$ \\
\hline
\end{tabular}

\section{Abstract}

This study identifies the impact of the tourism development of economic conditions surrounding community. This research was conducted in the village of Dieng, District Kejajar, Wonosobo regency. This research was done because of the rise in visitor attractions and tourism revenue that affect the economy of the surrounding community attraction. This research uses descriptive research method qualitative and quantitative data include both primary and secondary data. This study uses a Likert Scale tool to determine the results. The purpose of this study to describe the condition of tourism, and to identify the impact of the development of tourism on the economy of surrounding communities. The results of this study showed an increase in facilities and services, attraction after their development, but there is a decrease in the field of hygiene and security. The percentage of people's income has increased which is calculated using a Likert Scale from $53.3 \%$ to $68.5 \%$, the low employment rate with a percentage of only $29.5 \%$.

(C) 2017 Universitas Negeri Semarang

\footnotetext{
Alamat korespondensi:

Gedung L2 Lantai 2 FE Unnes

Kampus Sekaran, Gunungpati, Semarang, 50229

E-mail: irhamna.alim@gmail.com
} 


\section{PENDAHULUAN}

Pariwisata merupakan salah satu sektor yang dapat dikembangkan sebagai salah satu sumber pendapatan daerah pada umumnya dan pendapatan masyarakat sekitar pada khususnya. Dengan diberlakukannya UU No. 32 Tahun 2004, UU No. 33 Tahun 2004 yang memberikan kewenangan lebih luas pada Pemerintah Daerah untuk mengelola wilayahnya, membawa implikasi semakin besarnya tanggung jawab dan tuntutan untuk menggali dan mengembangkan seluruh potensi sumber daya yang dimiliki daerah dalam rangka menopang perjalanan pembangunan di daerah, dengan adanya UU tersebut Pemerintah Daerah memiliki keleluasaan untuk mengembangkan obyek wisata. Pengembangan pariwisata merupakan amanat UU No. 10 Tahun 2009 tentang Kepariwisataan yang menyatakan bahwa pemerintah bersama lembaga yang terkait dengan kepariwisataan menyelenggarakan penelitian dan pengembangan kepariwisataan untuk mendukung pembangunan kepariwisataan (pasal 11 UU No. 10 Tahun 2009). Pengembangan pariwisata di Indonesia bertujuan untuk mengurangi kemiskinan, melestarikan alam, lingkungan dan sumber daya, mengembangkan budaya, memperbaiki citra bangsa, dan memperkuat hubungan dengan negara lain (Sutawa, 2012).

Dataran Tinggi Dieng terhampar di ketinggian 2.093 meter diatas permukaan air laut memiliki udara yang begitu sejuk dengan selimut kabut tebal yang menutupinya. Suhu rata-rata di tempat ini adalah 10-20 derajad celcius. Kawasan Dieng masuk ke dalam dua wilayah kabupaten, yaitu Kabupaten Banjarnegara dan Kabupaten Wonosobo, Jawa Tengah. Wilayah terbesar dataran tinggi Dieng adalah milik Kabupaten Banjarnegara. Dieng terletak $26 \mathrm{~km}$ ke arah utara dari pusat Kota Wonosobo. Nama Dieng sendiri artinya daerah pegunungan atau dataran tinggi tempat para dewa dan dewi. Letaknya yang berada di dekat Gunung Sindoro dan Gunung Sumbing membuat kawasan ini terasa sejuk, bahkan dingin di malam hari.

Produk pariwisata utama adalah kunci menarik yang dapat menarik wisatawan ke tujuan tertentu (Benur \& Bill 2015). Kabupaten Wonosobo khususnya sektor pariwisata merupakan salah satu sektor yang strategis dan potensial untuk dikelola, dikembangkan dan dipasarkan terbukti dengan jumlah pengunjung Kawasan Wisata Dieng yang setiap tahunnya selalu meningkat. Berikut adalah grafik jumlah pengunjung Obyek Wisata Kawasan Dieng, Desa Dieng, Kecamatan Kejajar, Kabupaten Wonosobo.

Grafik di atas dapat dilihat bahwa pada tahun 2013 Dataran Tinggi Dieng mengalami peningkatan pengunjung menjadi 131.313 orang dari tahun sebelumnya yang hanya 125.603 orang, begitu pula Dieng Plateau Theater (DPT) juga mengalami peningkatan pengunjung menjadi 99.735 orang dari tahun sebelumnya yang hanya berjumlah 63.696 orang. Pengunjung Dataran Tinggi Dieng pada tahun 2014 mengalami penurunan menjadi 121.155 orang dari tahun sebelumnya yang berjumlah 131.313 , akan tetapi Dieng Plateau Theater (DPT) mengalami peningkatan drastis menjadi sebanyak 140.300 orang dari tahun sebelumnya yang hanya 99.735 orang. 
Sani Alim Irhamna / Economics Development Analysis Journal 6 (3) (2017)

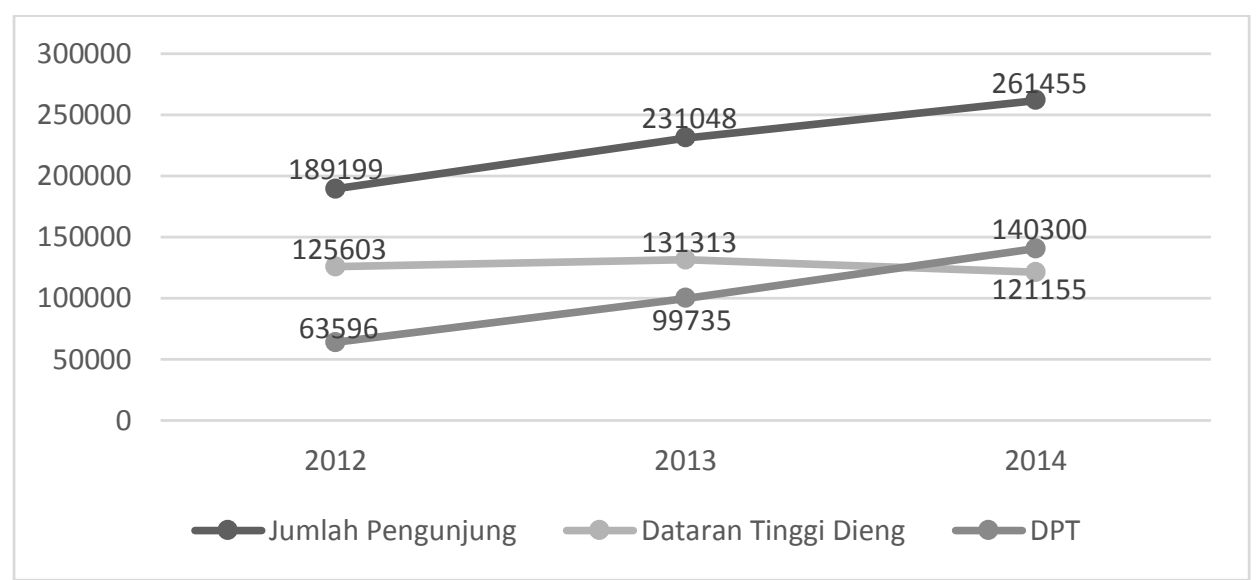

Gambar 1. Grafik Jumlah Pengunjung Obyek Wisata Kawasan Dieng

Sumber : Kantor Pariwisata dan Ekonomi Kreatif Kabupaten Wonosobo, BPS 2015

Jumlah pengunjung obyek wisata kawasan Dieng setiap tahunnya selalu meningkat dari tahun 2012-2014. Pada tahun 2012 jumlah pengunjung Kawasan Wisata Dieng sebanyak 189.199 orang dan pada tahun 2013 meningkat menjadi 231.048 orang, di tahun 2014 juga meningkat menjadi 261.455 orang.

Adanya peningkatan jumlah pengunjung maka secara langsung berdampak pada meningkatnya pendapatan retribusi obyek wisata yang nantinya juga akan berpengaruh pada bertambahnya Pendapatan Asli Daerah (PAD). Pendapatan retribusi yang didalamnya terdapat pendapatan restribusi wisata merupakan salah satu sektor yang paling berpengaruh dalam perolehan Pendapatan Asli Daerah, apalagi seperti Kabupaten Wonosobo yang memiliki potensi wisata sangat baik, ini tentunya harus lebih digalakkan dalam pengelolaan potensi tersebut sehingga dapat mencapai pendapatan daerah yang maksimal. Fitur dan pilihan produk pariwisata meliputi pengembangan produk pariwisata secara umum, diversifikasi paralel dan integrative serta sinergi tematik dan spasial antar produk (Benur \& Bill, 2015)

Berikut adalah grafik jumlah pendapatan retribusi Obyek Wisata Kawasan Dieng, Desa Dieng, Kecamatan Kejajar, Kabupaten Wonosobo. Grafik di atas dapat dilihat Dataran Tinggi Dieng mengalami peningkatan pendapatan pada tahun 2013 dari yang sebelumnya Rp. 477.291.000 menjadi Rp.
498.989.000, akan tetapi pada tahun 2014 mengalami penurunan menjadi Rp. 460.389.000. Sedangkan Dieng Plateau Theater (DPT) mengalami peningkatan pada setiap tahunnya dari tahun 2012 sebesar Rp. 240.984.000, tahun 2013 Rp. 377.926 .000 hingga tahun 2014 menjadi sebesar Rp. 531.639.000. Jumlah keseluruhan pendapatan retribusi Kawasan Wisata Dieng pada tahun 2012-2014 selalu meningkat, pendapatan tahun 2012 adalah sebanyak Rp. 718.275.000, dan pada tahun 2013 meningkatan menjadi sebanyak $\mathrm{Rp}$. 876.915.000, di tahun 2014 juga mengalami peningkatan yang cukup drastis menjadi sebanyak Rp. 992.028.000. Hal ini menunjukkan bahwa Kawasan Wisata Dieng mengalami perkembangan dengan meningkatnya jumlah wisatawan dan pendapatan retribusi yang didapat, maka secara langsung maupun tidak langsung akan menambah pendapatan masyarakat sekitar obyek wisata dengan melakukan usaha-usaha di sekitar obyek wisata seperti jual beli barang atau jasa. Pengembangan pariwisata tentu saja akan memberikan dampak baik itu dampak positif maupun dampak negatif. Suatu tempat wisata tentu memiliki dampakdampak terhadap lingkungan sekitarnya. "as tourism grows and travelers increases, so does the potential for both positive and negative impacts" (Gee, 1989, diperoleh dari http://jurnalsdm.blogspot.co.id). 
Sani Alim Irhamna / Economics Development Analysis Journal 6 (3) (2017)

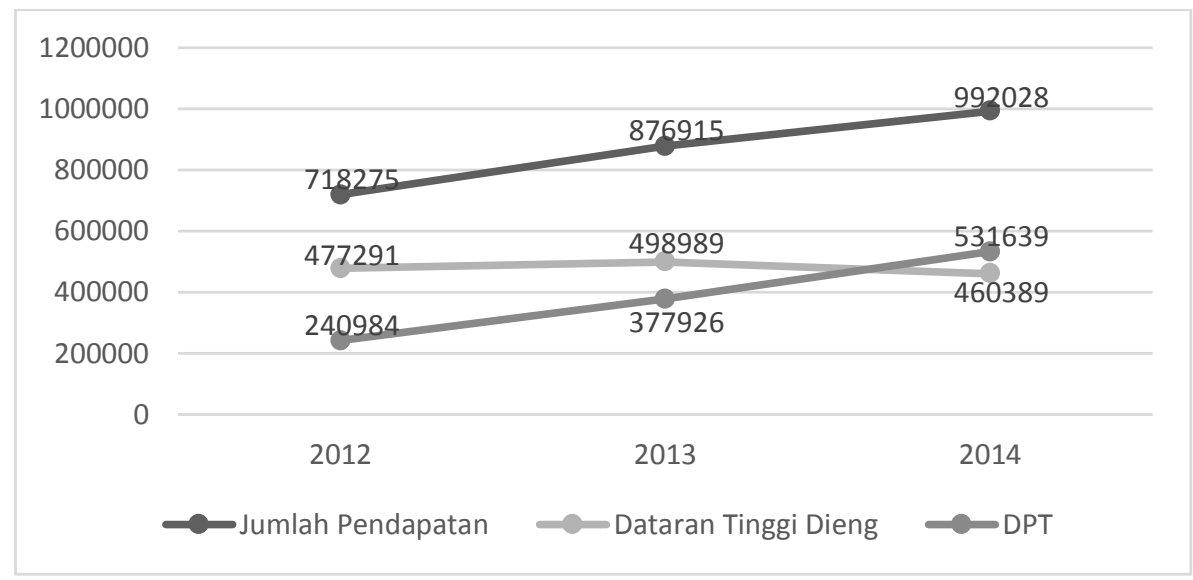

Gambar 2. Grafik Jumlah Pendapatan Retribusi Obyek Wisata Kawasan Dieng Kabupaten Wonosobo Tahun 2012-2014

Sumber : Kantor Pariwisata dan Ekonomi Kreatif Kabupaten Wonosobo. BPS 2015

Pernyataan tersebut sejalan dengan Pendit (1990), pariwisata mampu menghasilkan pertumbuhan ekonomi, karena dapat menyediakan lapangan kerja, menstimulasi berbagai sektor produksi, serta memberikan kontribusi secara langsung bagi kemajuankemajuan dalam usaha-usaha yang dapat memberikan keuntungan dan kesenangan baik kepada masyarakat setempat maupun wisatawan. Wisata alam merupakan salah satu potensi yang dimiliki Kabupaten Wonosobo, dengan adanya panorama alam yang indah dan suasana objek wisata yang asri memberikan kenyaman bagi pengunjung maka pengunjung tidak bosan dalam berkunjung (Pradikta 2013:10) Berdasarkan fenomena ini maka perlu diadakan penelitian mengenai dampak-dampak yang ditimbulkan dari adanya perkembangan pariwisata terhadap perekonomian masyarakat sekitar obyek wisata, mengingat bahwa Kawasan Wisata Dieng merupakan salah satu kawasan pariwisata potensial andalan Kabupaten Wonosobo. Kualitas hidup secara keseluruhan merupakan prediktor yang efektif untuk mendukung pengembangan pariwisata lebih lanjut (Woo, et al., 2014).

Berdasarkan latar belakang atas, maka rumusan masalah dalam penelitian ini yaitu : Bagaimana gambaran kondisi pariwisata di Dieng Kabupaten Wonosobo?; Bagaimana dampak pengembangan obyek wisata terhadap perekonomian masyarakat sekitar obyek wisata?.

Adapun tujuan dalam penelitian ini yaitu : Menggambarkan kondisi pariwisata di Dieng Kabupaten Wonosobo; Mengidentifikasi dampak yang ditimbulkan dari adanya pengembangan obyek wisata terhadap kondisi perekonomian masyarakat sekitar.

\section{METODE PENELITIAN}

Penelitian ini menggunakan metode penelitian analisis deskriptif. Menurut Sugiyono (2012:6) penelitian berdasarkan tingkat eksplanasinya, penelitian deskriptif adalah penelitian yang dilakukan untuk mengetahui nilai variabel mandiri, baik satu variabel atau lebih tanpa membuat perbandingan, atau menghubungkan dengan variabel yang lain. Analisis deskriptif adalah statistik yang digunakan untuk menganalisis data dengan cara mendeskripsikan atau menggambarkan data yang telah terkumpul sebagaimana adanya tanpa bermaksud membuat kesimpulan yang berlaku untuk umum atau generalisasi.

Populasi dalam penelitian ini adalah seluruh pelaku usaha yang ada di sekitar obyek wisata dan pengelola obyek wisata, sampel dalam penelitian ini berjumlah 97 responden yang meliputi, pegawai obyek wisata, pedagang, jasa penginapan, jasa wc umum, pengamen, juru 
parkir, dan 3 informan yang meliputi, Kantor Pariwisata Dan Ekonomi Kreatif, Perangkat Desa Dieng, pengelola Obyek Wisata.

Metode pengumpulan data menggunakan observasi sebagai studi pendahuluan untuk menemukan masalah. Observasi dilakukan dengan cara mengamati perkembangan obyek wisata dan para pelaku usaha di sekitar obyek wisata. Kuesioner /angket merupakan teknik pengumpulan data yang dilakukan dengan cara memberi seperangkat pertanyaan atau pernyataan tertulis kepada responden untuk dijawabnya (Sugiyono, 2015:199). Pada penelitian ini angket menggunakan rentang yang sudah ditentukan menggunakan Skala Likert. Wawancara menurut Sugiyono (2015:194) "Wawancara digunakan sebagai teknik pengumpulan data apabila ingin melakukan studi pendahuluan untuk menemukan permasalahan yang harus diteliti dan juga apabila peneliti ingin mengetahui hal-hal dari responden yang lebih mendalam dan jumlah respondennya sedikit/kecil", dalam penelitian ini wawancara digunakan untuk memperkuat hasil dari angket/kuesioner. Dokumentasi digunakan karena ingin mengetahui data-data yang mempunyai relevansi dengan tujuan penelitian sehingga dapat memudahkan kegiatan penelitian. Dokumentasi digunakan untuk memperoleh data tentang gambaran kondisi pariwisata di Dieng Kabupaten Wonosobo.

Uji instrumen penelitian menggunakan uji validitas dan reliabilitas. Ghozali (2013:52) uji validitas yaitu untuk mengukur sah atau valid tidaknya suatu kuesioner. Suatu kuesioner dikatakan valid jika pertanyaan pada kuesioner mampu untuk mengungkapkan suatu yang akan di ukur oleh kuesioner tersebut yang dilakukan dengan membandingkan nilai $\mathrm{r}$ hitung (correlated item total correlations) dengan nilai $r$ tabel. Apabila nilai $r$ hitung $>r$ tabel dan bernilai positif maka pernyataan tersebut dikatakan valid (Ghozali, 2013:49). Pengujian instrumen dalam penelitian ini menggunakan sampel sebanyak 30 responden (Sugiyono, 2015:128). Adapun nilai $r$ tabel pada $\mathrm{df}=(\mathrm{n}-2)$ atau $30-2=28$ dengan tingkat probabilitas kesalahan $5 \%$ atau 0.05 yaitu 0,3610 . Ghozali (2013:47), Reliabilitas adalah alat untuk mengukur suatu kuesioner yang merupakan indikator dari variabel atau konstruk. Suatu kuesioner dikatakan reliabel atau handal jika jawaban seseorang terhadap pernyataan adalah konsisten atau stabil dari waktu ke waktu. Salah satu cara untuk menguji ini adalah dengan melihat nilai Cronbach Alpha yang terbentuk.

Metode analisis data dalam penelitian ini disesuaikan dengan jenis data yang berhasil diperoleh pada saat penelitian dilakukan. Dengan menggunakan Skala Likert untuk mengukur sikap, pendapat, dan persepsi seseorang atau sekelompok orang tentang fenomena sosial (Sugiyono 2012:107). Kuesioner dalam pilihan ganda dimana setiap item soal disediakan 4 (empat) jawaban dengan skor masing-masing sebagai berikut:

Tabel 1. Skala Penilaian Jawaban Responden

\begin{tabular}{llll}
\hline No. & Jawaban & Skor & $\begin{array}{c}\text { Persentase } \\
\text { Nilai }\end{array}$ \\
\hline 1. & A & 4 & $76 \%-100 \%$ \\
2. & B & 3 & $51 \%-75 \%$ \\
3. & C & 2 & $26 \%-50 \%$ \\
4. & D & 1 & $0 \%-25 \%$ \\
\hline
\end{tabular}

Rumus Skala Likert : $\boldsymbol{\Sigma}(\boldsymbol{T} \boldsymbol{x} P \boldsymbol{n})=N$

Keterangan :

$\mathrm{T}=$ Total jumlah responden yang memilih

$\mathrm{Pn}=$ Pilihan angka skor likert

$\mathrm{N}=$ Total skor

Interpretasi skor perhitungan :

Kategori $=\frac{N}{Y} \times 100 \%$

Keterangan :

$\mathrm{Y}=$ Skor tertinggi $\mathrm{x}$ Jumlah Resonden

Analisis data yang digunakan dalam penelitian ini adalah deskriptif yang dilengkapi data kuantitatif dan kualitatif, yaitu dari fakta diketahui secara konkrit, kemudian kemudian digeneralisasikan ke dalam suatu kesimpulan yang bersifat umum dan didasarkan pada faktafakta empiris tentang lokasi penelitian. Metode deskriptif dipilih karena yang menjadi fokus dalam penelitian ini adalah dampak dari pengembangan obyek wisata di Dieng, 
Kabupaten Wonosobo terhadap perekonomian masyarakat sekitar obyek wisata. Untuk mengetahui dampak pengembangan pariwisata terhadap perekonomian masyarakat sekitar obyek wisata, diperlukan adanya data kondisi masyarakat sebelum dan sesudah pengembangan pariwisata yang meliputi kondisi ekonomi masyarakat sekitar obyek wisata.
Untuk mengetahui kesempatan kerja masyarakat setempat maka dapat dianalisis dengan menggunakan metode perhitugan kesempatan kerja yaitu (Paramitasari 2010:48) :

$$
\text { Kesempatan Kerja }=\frac{\text { Jumlah Penduduk Bekerja }}{\text { Jumlah Penduduk Usia Produktif }} \times 100 \%
$$

Kemudian penghitungan kesempatan kerja penduduk setempat dikategorikan sebagai berikut :

$\leq 50 \%$ maka kesempatan kerja penduduk wilayah penelitian mempunyai nilai yang rendah.

$\geq 50 \%$ maka kesempatan kerja penduduk wilayah penelitian mempunyai nilai yang tinggi.

\section{HASIL DAN PEMBAHASAN}

Untuk mengetahui dampak pengembangan pariwisata terhadap perekonomian masyarakat sebelum dan sesudah pengembangan pariwisata maka diperlukan indikator penelitian, adapun indikator tersebut adalah tingkat pendapatan dan kesempatan kerja.

\section{Tingkat Pendapatan}

Pendapatan adalah penghasilan yang diperoleh setelah melakukan usaha di sektor pariwisata. Masyarakat mendapat penghasilan jika mereka bekerja dan mendapat upah dari pekerjaan di sektor pariwisata. Hasil penelitian menyatakan bahwa tingkat pendapatan masyarakat yang melakukan usaha di sekitar objek wisata adalah seperti pada tabel 2 .
Berdasarkan tabel diatas dari 97 responden pelaku usaha yang dijadikan objek penelitian menghasilkan pada rentang pendapatan $0-\mathrm{Rp}$. $500.000,00$ sebelum dilakukan pengembangan ada sebanyak 43 responden atau sekitar 44,4\% dari seluruh responden, sedangkan sesudah adanya pengembangan ada 21 responden yang artinya pada rentang ini terjadi penurunan.

Untuk rentang pendapatan Rp. 501.000,00 - Rp. 1.000.000,00 sebelum adanya pengembangan ada 19 responden atau sekitar $19,6 \%$ dari seluruh responden, sesudah dilakukan pengembangan ada 17 responden atau sekitar $17,5 \%$ dari seluruh responden, perubahan ini dikarenakan ada beberapa responden yang mengalami peningkatan pendapatan, dan untuk rentang Rp. 1.001.000,00 - Rp. 1.500.000,00 sesudah dilakukan pengembangan ada peningkatan sekitar $90 \%$ dari yang sebelum pengembangan berjumlah 14 responden sesudah pengembangan menjadi 25 responden.

Sedangkan untuk rentang pendapatan lebih dari Rp. 1.501.000,00 sebelum adanya pengembangan ada 21 responden dan sesudah pengembangan ada sebanyak 34 responden, yang artinya terjadi peningkatan sebanyak 13 responden atau sekitar 63,6\%. Rata-rata pendapatan berdasar rentang pendapatan yang ada dapat dihitung menggunakan Skala Likert pada gambar berikut. 
Tabel 2. Pendapatan Pemilik Usaha Di Area Objek Wisata Kawasan Dieng Sebelum Dan Sesudah Pengembangan

\begin{tabular}{lllll}
\hline \multirow{2}{*}{ Rentang } & \multicolumn{2}{l}{ Sebelum } & \multicolumn{2}{l}{ Sesudah } \\
\cline { 2 - 5 } & F & $\%$ & F & $\%$ \\
\hline > Rp. $1.501 .000,00$ & 21 & $21,6 \%$ & 34 & $35,1 \%$ \\
Rp. $1.001 .000,00-$ Rp. $1.500 .000,00$ & 14 & $14,4 \%$ & 25 & $25,7 \%$ \\
Rp. 501.000,00 - Rp. $1.000 .000,00$ & 19 & $19,6 \%$ & 17 & $17,5 \%$ \\
0 - Rp. 500.000,00 & 43 & $44,4 \%$ & 21 & $21,7 \%$ \\
\hline Jumlah & 97 & $100 \%$ & 97 & $100 \%$
\end{tabular}

Sumber : Data Primer Diolah, 2016

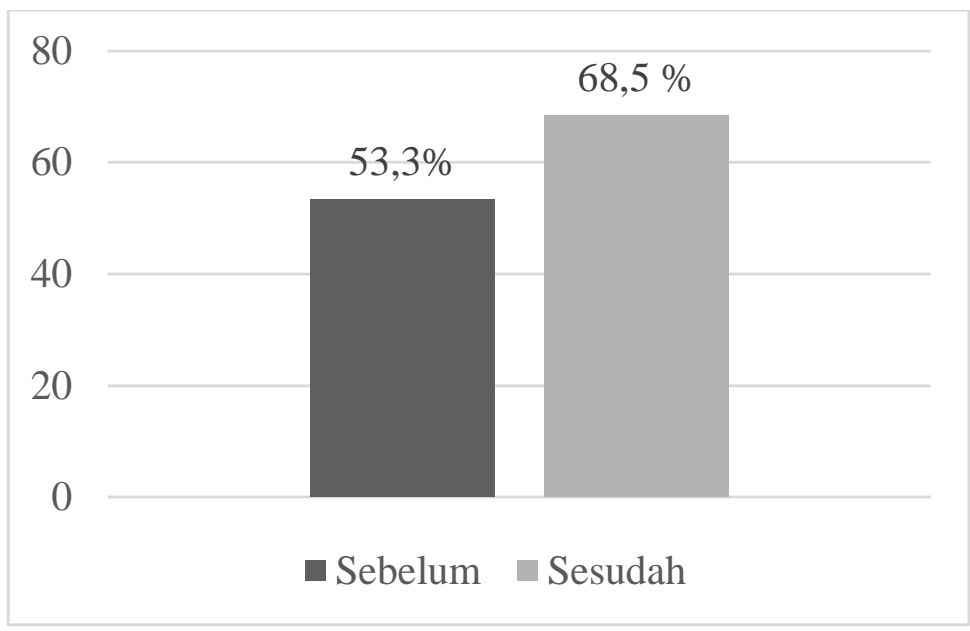

Gambar 3. Grafik Pendapatan Pemilik Usaha Di Area Objek Wisata Kawasan Dieng Sebelum Dan Sesudah Pengembangan

Sumber : Data Primer Diolah, 2016

Dari grafik diatas menghasilkan pendapatan pelaku usaha sebelum adanya pengembangan memperoleh persentase sebesar $53,3 \%$ yang berarti termasuk dalam rentang Rp. 1.001.000,00 - Rp. 1.500.000,00, sesudah adanya pengembangan meningkat dari sebelum adanya pengembangan menjadi sebesar $68,5 \%$ yang berarti tetap berada pada rentang $\mathrm{Rp}$. 1.001.000,00 - Rp. 1.500.000,00, akan tetapi lebih mendekati pada rentang lebih dari Rp. 1.501.000,00, hal ini menunjukkan bahwa dengan adanya pengembangan obyek wisata akan menambah pendapatan pelaku usaha di sekitar Objek Wisata Kawasan Dieng.

\section{Kesempatan Kerja}

Ketersediaan lapangan kerja akan berpengaruh terhadap kesempatan kerja dan usaha. Kesempatan kerja yang dimaksud adalah besarnya serapan angkatan kerja masyarakat di dalam wilayah penelitian akibat adanya aktifitas pariwisata yang berlangsung di objek wisata Kawasan Dieng. Semakin banyak peluang kerja maka pengaruh positif yang diberikan oleh aktifitas dalam menciptakan lapangan kerja dan mengurangi tingkat pengangguran semakin besar. Untuk mengetahui kesempatan kerja masyarakat setempat maka dapat dianalisis dengan menggunakan metode perhitugan kesempatan kerja yaitu (Paramitasari 2010:48) : 


$$
\text { Kesempatan Kerja }=\frac{\text { Jumlah Penduduk Bekerja }}{\text { Jumlah Penduduk Usia Produktif }} \times 100 \%
$$

Menurut Nawawi selaku Kepala Urusan Ekonomi dan Pembangunan Desa Dieng, Kecamatan Kejajar, Kabupaten wonosobo dalam hasil wawancara pada tanggal 20 Juli 2016, beliau menyatakan bahwa "jumlah penduduk yang bekerja di industri pariwisata berjumlah 120 orang dan jumlah penduduk usia produktif (15-64tahun) berjumlah 407 orang".

Berdasar pernyataan Nawawi tersebut dapat dihitung kesempatan kerja sebagai berikut: Kesempatan kerja $=\frac{120}{407} \times 100 \%$ Kesempatan kerja $=29,5 \%$

Kesempatan kerja di Dieng, Kecamatan Kejajar, Kabupaten Wonosobo menghasilkan persentase sebesar $29,5 \%$ yang berarti $\leq 50 \%$ maka kesempatan kerja penduduk mempunyai nilai yang rendah.

Masalah atau kendala yang timbul dalam proses pengembangan yaitu masalah kebersihan seperti yang dikatakan Haryono, bahwa kebersihan adalah hal yang penting dalam meningkatkan daya tarik wisata. Begitu pula kesadaran masyarakat akan pariwisata merupakan suatu masalah, dalam proses pengembangan harus ada dukungan dari masyarakat sekitar paling tidak untuk menjaga dan mensosialisasikan objek wisata yang ada sehingga dapat lebih menarik para pengunjung.

\section{SIMPULAN}

Berdasarkan hasil penelitian dan pembahasan yang telah dijelaskan pada bab sebelumnya, maka dapat diambil kesimpulan kondisi objek wisata sesudah adanya pengembangan dari segi, fasilitas, dan pelayanan semakin bagus akan tetapi untuk segi keamanan dan kebersihan masih kurang bagus bahkan semakin buruk. Dampak yang ditimbulkan terhadap perekonomian masyarakat sekitar dari adanya pengembangan objek wisata di Dieng, Kecamatan Kejajar, Kabupaten Wonosobo adalah meningkatkan pendapatan masyarakat dan meningkatnya kesempatan kerja.
Saran yang dapat diberikan berdasarkan hasil penelitian yang telah dilakukan adalah kesadaran masyarakat terutama pengunjung akan kebersihan harus lebih ditingkatkan melalui himbauan secara langsung melalui tulisan yang diletakkan pada sekitar objek wisata dan menambah fasilitas tempat sampah yang ada, untuk meningkatkan dalam segi keamanan dengan menambah personil pegawai objek wisata terutama satpam. Pengelolaan dan pengembangan objek wisata akan lebih baik jika dikelola penuh oleh Kantor Pariwisata dan Ekonomi Kreatif (PAREKRAF), sehingga dari master plan hingga pelaksanaannya semua dapat terkelola dengan baik karena PAREKRAF yang paling mengerti tentang pariwisata sehingga nantinya akan lebih memberikan dampak positif terhadap masyarakat sekitar pada khususnya dan masyarakat Kabupaten Wonosobo pada umumnya.

\section{DAFTAR PUSTAKA}

BPS Wonosobo. 2015. Wonosobo Dalam Angka. Badan Pusat Statistik Kabupaten Wonosobo.

Benur, Abdelati M \& Bill Bramwell. Tourism product development and product diversification in destinations. Tourism Management, Volume 50, Pages 213-224

Ghozali, Imam. 2011. Aplikasi Analisis Multivariate dengan Program IBM SPSS 19. UNDIP. Semarang.

Paramitasari, Isna D. 2010. Dampak Pengembangan Pariwisata Terhadap Kehidupan Masyarakat Lokal. Surakarta.

Pendit, Ny S. 1990. Ilmu Pariwisata, Sebuah Pengantar Perdana. Jakarta: PT Pandnyana Paramita.

Pradikta, Angga. 2013. Strategi Pengembangan Obyek Wisata Waduk Gunungrowo Indah Dalam Upaya Meningkatkan Pendapatan Asli Daerah (Pad) Kabupaten Pati. Economics Development Analysis Journal, 2(4). doi:10.15294/edaj.v2i4.2478

Riduwan. 2005. Belajar Mudah Penelitian Untuk Guru, Karyawan dan Peneliti Pemula. Bandung: Alfabeta. 
Sugiyono. 2015. Metode Penelitian Pendidikan Pendekatan Kuantitatif, Kualitatif dan R\&D. Bandung: Alfabeta.

Sugiyono. 2012. Metode Penelitian Administrasi. Cetakan ke 20. Bandung: Alfabeta.

Sugiyono. 2012. Metode Penelitian Pendidikan Pendekatan Kuantitatif, Kualitatif, dan R\&D. Bandung: Alfabeta.

Dampak Pengembangan Obyek Wisata : Dampak Positif Dampak Negatif. http://jurnalsdm.blogspot.co.id/2009/08/d ampak-pengembangan-onyek-wisatadampak.html. Diakses pada tanggal 28 Februari 2016 pukul 12.34 WIB.

Sutawa, Gusti Kade. 2012. ssues on Bali Tourism Development and Community Empowerment to Support Sustainable Tourism Development. Economics and Finance, Volume 4, Pages 413-422.

Woo, Eunju, et al. 2014. Life satisfaction and support for tourism development. Annals of Tourism Research, Volume 50, Pages 84-97 